\title{
Barriers to Use of Educational Technology in the Learning Process of Primary School Students in District 13 in Tehran
}

\author{
Esfandiar Doshmanziari ${ }^{1} \&$ Aida Mostafavi $^{2}$ \\ ${ }^{1}$ Department of educational management, West Tehran Branch, Islamic Azad University, Tehran, Iran \\ ${ }^{2}$ Department of educational management, Tehran Branch, Islamic Azad University E-Campus, Iran \\ Correspondence: Esfandiar Doshmanziari, Department of educational management, West Tehran Branch, Islamic \\ Azad University, Tehran, Iran. E-mail: doshmanziari@gmail.com
}

\author{
Received: April 4, 2016 \\ Accepted: May 17, 2016 \\ Online Published: January 30, 2017 \\ doi:10.5539/ies.v10n2p44 \\ URL: http://dx.doi.org/10.5539/ies.v10n2p44
}

\begin{abstract}
The aim of this study was to examine the barriers to use of educational technology in the learning process of primary school students in district 13 of Tehran. This research in terms of purpose is practical, in terms of the title characteristics of the research is descriptive, and in terms of data collection method is a field research. The statistical population is 350 people, consisted of all primary school teachers and administrators for girls in district 13 of Tehran in the academic year of 2016-2017. Random sampling was simple and available. The sample size was calculated about 124 people based on Cochran formula. In this research, a questionnaire was used to collect data. Content validity of the questionnaire was approved by using expert and corrective opinions of some teachers and subject specialists, and to determine the reliability of the questionnaire the Cronbach's alpha coefficient was used. In order to analyze the collected data, the proportional statistical tests such as correlation coefficients and regression analysis were used that in this regard, the spss statistical software was used. The research results showed that 4 human, cultural, and physical factors and courses content can create barriers in the use of educational technology in the process of student learning.
\end{abstract}

Keywords: educational technology, students' learning, primary schools, Tehran

\section{Introduction}

In recent decades, many efforts have been made in the country so that the stereotypes and traditional teaching methods were replaced by new and innovative approaches based on individual and social needs of the students. These approaches will nature the students to become creative and knowledge producer and will provide new openings in the field of technology and science. Changes in the educational system and students' textbooks have also been made in this regard. However, despite all the efforts and the heavy costs that the department of education has been incurred, we are still witnessing traditional and teacher-centered in teaching science. The causes of the traditional teaching persistence methods can be pursued within the following factors (Ahadian, Mohammad Aghazadeh, \& Muharram, 2000).

1) The effect of the educational system program and its structuring in the teaching process: the construction of the educational system in a society, including attitudes and beliefs, plans and regulations could affect the teacher's teaching method. Educational system attention or inattention to the needs of students and society, the authenticity of the educational system to the contents and programs rather than a comprehensive development, lack of supervision and healthy control and appropriate and inappropriate evaluations all can affect the teacher's teaching method. In reviewing the structure of the educational system of each country, there are two completely different systems.

2) A system based on the originality of the course material: one of the system characteristic based on the originality of the course material is that in this educational, a stable program will be run in the country and the program content is bound to the setting text and uniform discipline observing are required for all teachers.

3) A system based on individual's all-round development: in this system, the program will be set according to the regional requirements and the type of school and students' ability and the program content will be set to individual and group activities of students and the program content depends on individual and group activities of students. Teachers have more freedom and authority in running the program and the selection of course materials, 
etc. With a little hesitation and attention in the educational system of the country, we find out that our country educational system depends on the originality of the course materials. Because the teachers have to teach certain contents regardless of abilities, talents and interests of students, and make a certain evaluation with specific sub scores.

4) Lack of teachers' familiarity with new educational methods: Although teachers are widely recommended to replace traditional and teacher-centered methods with active educational methods, involve students in practical and researching issues and sometimes different ways, such as the use of ICT in education, laboratory methods, project, FAQ, etc. will be recommended to teachers for teaching, still large numbers of teachers just familiar with the titles of these teaching methods or have very limited information.

5) Time mismatching with the active methods of the time can be considered from two angles, the first one is the lack of required time for teaching science through active way, which means the teaching time of active methods is longer than the traditional methods of the past. The second one is the lack of students' time to work and study. Students need peace and time to carry out activities, projects, group discussions that led to the desired results. Because, certainly doing homework by students, which resulting in high levels of learning in the cognitive domain, has required more time.

6) The lack of facilities in rural and underserved areas: a good teacher can be effective in limited circumstances. But there is no doubt that space and appropriate educational facilities and selection of teachers' teaching method are very effective. Diversity of students, lack of enough tables and chairs, no libraries, laboratories, computer sites and...can affect the teacher's teaching methods.

7) Lack of coordination and controlling of external factors: In addition to the above problems, many effective external factors influence on the style and performance of teachers, some of which include:

Failure to control and monitor in scientific publications and out-of-school educational institutions: Although several efforts have been done to provide questions and very interesting and varied activities in textbooks, but the lack of proper oversight in some of the high-circulation publications are published; The implication of these discussions is destroyed the book, as well as some jobber educational institutions that sometimes have diverse purposes with educational books, imposes serious problems.

Lack of parents' awareness: due to the lack of parents' familiarity with modern teaching methods, the teachers and students both are facing serious problems in using active teaching methods.

Educational technology in our country has lesser-known expertise, despite the efforts of educational authorities and some of the teachers who have taken steps in this direction, but it still has difficulties in using this matter. As a result, knowing a large number of teachers of educational technology is already limited in much the same audio-visual equipment and teaching aids (Enayati et al., 2011).

However, the world that we live in is constantly changing. Therefore, the educational system should provide the students' learning ability so that they potentially will be able to adapt themselves to the conditions of constantly changing human knowledge. On the other hand, we must accept the fact that the teacher era as the only omnipotent and the only teaching force Almighty came to the end and chest to chest teaching, traditional teaching methods and learning based on pure theory, to respond to the unlimited and unexpected fields resulted from diversity changes in the human knowledge developments had not required efficacy anymore and will not meet the demands of the educational requirements of our time, because students in our time, out of the classroom exposure to the unconscious learning process instruments that the educational technology and its continuous evolution is appointed to serve the community. Following the increasing knowledge of students, their expected level of knowledge and teachers' awareness has gone up that in addition to the teacher, the library cannot be the only source of getting information about all the Science and new educational technologies of the world and their educational needs. The only way to overcome the crisis that is affecting our educational system is to create and fertilize the culture of educational technology and new methods of teaching and designing regular training system will help us in some extent to solve the problems.

With respect to the mentioned requirements and an urgent and growing educational system need of our country to educational technology, in this study, the author studies the barriers to the use of educational technology in teaching and learning process based on researches and scientific findings, he is looking for clarifying the obstacles in the way of the educational technology used in the learning process of primary school students. Therefore, the main research question is whether the human, physical, cultural elements and content of courses affected as a barrier to the development and usage of educational technology in primary schools or not? 


\section{Theoretical Foundations}

\subsection{Educational Technology}

Educational technology means the design, implementation, and regular evaluation of all the teaching and learning process by setting specific targets and taking advantage of all the human and material resources of the learning psychology and social communication in order to provide effective teaching and learning conditions (Ahadian, 2008).

Educational technology in advanced societies for better learning science plays a major role. At the beginning of the twentieth century, the positivist epistemological approach was employed in the creating and developing process of all scientific fields and the educational technology field, which at that time was known just as (audiovisual), was not an exception from this principle. This approach was focused on the independent knowledge existence in the student's mind and based on the task, was considered the training as knowledge transferring to the student's mind and the evaluation was based on a judgment about the accuracy of the knowledge. This objective approach acknowledged to the different perceptions of education in people, but it considered the goal of education in achieving the correct understanding or teacher perception. However, today, the meaning of educational technology is not the use of educational materials anymore, but it means training engineering, designing and architecture training. In other words, engineering is an educational process. Therefore, as a building needs a design, an engineer, and an architect, an education system needs an educational technology.

One of the issues that our educational system, especially educational department is facing is the lack of teachers and educators and also administrators and authorities' familiarity with educational technology and its employment in the process of teaching and learning and this problem like other issues roots in our education system. Educational technology in education is like a lamp that is placed at the feet of education path walkers, so that with its radiation, enlighten unknown and dark paths.

For the use of advanced technology and modern teaching aids, the basis should be provided for the creation and transmission in the community and current education and training methods of the educational system should be modified. Unfortunately, regardless of the education authorities' efforts, but still there is not appropriate conditions in education and training and not using of scientific and technological methods in teaching and learning process has brought a serious injury to the body of education and training (Veladkofsky, 2011).

\subsection{The Educational Technologist}

The definition that the educational technology is like a bridge between necessities and resources and is between hypothesis and action will show clearly the role of educational technology as a linked system. In this case, we can predict two kinds of expertise for an educational technologist.

1) Technologist as a general expert in different fields of education.

2) The educational technologist as a special education expert in a very limited field.

The first specialty: it means the educational technologist as a general expert of education and training issues, has many similarities to the so-called general practitioner. As a general practitioner has information and expertise in different fields of medical science, an educational technologist can also acquire enough skill in all types of education and training expertise. The territory of this expertise is not limited; in fact, it involves the work-related the teaching and learning process activities.

About the second opinion, which means: an educational technologist as a special expert, the domain of activity and skill will be limited to each available specialty in education and training matter? In this case, the educational technologist has the power of understanding and qualification and high scrutinizing in a field of training.

Mitchell believes five functions or tasks in connection with the general duty of an educational technologist as a career, as follows:

1) Consultant in internships

2) The educational materials producer (production and evaluation of educational materials)

3) The Director of the Center for Educational Resources

4) The educational systems developer

5) Educational Planning

With a little care, we find that the internship consulting activities is very broad and different. One of his major preoccupations should be decision-making related to the preparation, organization and purchasing of educational 
equipment, accurately identify training needs, determine the internship methods and providing appropriate solutions in this regard.

Activities related to the production and evaluation of educational materials are diverse, and the simplest ones are leveling the content, designing the messages, creating the evaluation, selecting the skills and techniques based on the content.

An educational technologist should use techniques to expand the simple educational system, most of the time he plays the role of a coordinator and will be within a group with multiple systems. The truth is that in order to get healthy benefits of educational technology in education and training course and determining his duties, we have been faced with the question that what educational technology development a technologist occupational field in Iran should be?

It is necessary to take this matter to your consideration that the title of educational technologist is not determining a specific type of occupation, but this term refers to those who disagree with each other about different training fields, for example, ((Mitchell)) mentions the fields that educational technologists have been active in them as follows:

- Determination of Educational Media

- Research and development of educational communication

- Setting program education

- $\quad$ The provision of educational TV programs

- Preparing materials for learning via image and audio

- Developing educational films

- The use of information technology (Informatics) in visual and audio learning tools (audiovisual)

- The organization and management of educational resources

- Publication of educational concepts of educational system and educational communication

- To establish the relationship between educational technology and some professions

From Mitchell's point of view, it clearly observed that the most activities of educational technologists connect with the media somehow.

\section{History of Research}

Enayati et al. (2011), in a study entitled the study of the teacher's benefits of educational technology barriers in teaching and learning process among teachers with a study of the secondary objective in human, cultural, physical obstacles and course content in educational technology benefits and this research was conducted in Minoodasht city in the academic year of 2010-2011 of 150 people. The results showed that human, cultural, physical obstacles and the course content are very meaningful in benefiting from educational technology.

Constantino (2014) in a study entitled 'Educational Technology and Teacher's Education and training' : Barriers in South America, have been discussed about the relation of the conflict between educational technology and educational and training teacher, and he considered this as a historical phenomenon, in this research the relation between educational technology (ET ) and teachers' education (TE) is considered as a barrier and the strategy in this regard, is focused on this study that adoption in this regard and education can make this obstacle to become more blurred.

Park and Ertmer (2008) in a research entitled 'the study of barriers in educational technology based on learning': by using systems performance support has studied the concentration barriers when the middle school teachers resistance toward advanced techniques.

The results show that the lack of common clear vision was the main obstacle. Additional barriers include a lack of knowledge and skill, unclear expectations and adequate feedback was impressive. Recommendations are provided to support the efforts of teachers to integrate increasing learning technology based on solving the problem.

\section{Research Methodology}

This research in terms of objective is an applied research. In fact, the aim of this study is to develop practical knowledge in a specific field. Moreover, this research in terms of topic characteristics is a descriptive research, in terms of data collection time, is a survey study and in terms the data collection method is a field study. The statistical population consists of all girls' primary school teachers and administrators in the academic year of 
2016-2017 in district 13 of Tehran about 350 people. Random sampling is simple and available. The sample size was calculated based on Cochran's formula in nearly about 124 people. In this study, to collect data, the documentation, library and internet methods, as well as a survey with a questionnaire were used. Content validity of the questionnaire was approved by using expert and corrective opinions of some teachers and subject specialists, and to determine the reliability of the questionnaire, the Cronbach's alpha coefficient was used. The calculated Alpha for the research questionnaire was 0.93, which is because it was more than 0.7 showed a suitable and acceptable reliability of research tool. In order to analyze the data collected, appropriate statistical tests such as correlation coefficients and regression analysis were used that in this regard, the SPSS statistical software is benefited.

\section{Research Results}

\subsection{The Normality Test}

During investigation of our data normalization, the null hypothesis, which is based on the normal distribution of data, will be tested at the level of $5 \%$. Therefore, if the test statistic obtained greater than or equal to 0.05 , it means that the data is normally distributed. According to the results of Kolmogorov-Smirnov test, it can be observed that the data distribution related to each variable is normal.

Table 1. The test result of Kolmogorov-Smirnov

\begin{tabular}{llcccc}
\hline & & Human Factors & $\begin{array}{c}\text { Cultural } \\
\text { Factors }\end{array}$ & Physical Factors & Courses content \\
\hline Quantity & & 124 & 124 & 124 & 124 \\
\hline \multirow{2}{*}{ Normal Parameters } & Average & 3.9750 & 3.2381 & 3.5773 & 4.1353 \\
\cline { 2 - 6 } & Standard deviation & .68426 & .67293 & .67302 & .69478 \\
\hline \multirow{2}{*}{ The most difference } & Absolute & .118 & .121 & .108 & .101 \\
\cline { 2 - 6 } & Positive & .057 & .064 & .056 & .097 \\
\cline { 2 - 6 } & Negative & -.113 & -.125 & -.135 & -.122 \\
\hline Kolmogorov - Smirnov & & 1.760 & 1.745 & 1.572 & 1.485 \\
\hline A significant factor & & .088 & .076 & .098 & .084 \\
\hline
\end{tabular}

\subsection{Hypotheses Test}

The first main hypothesis: the human factors as the development and extension of educational technology obstacles have impacts on the teaching process in primary schools.

Table 2. Regressions between human factors and the development of educational technology

\begin{tabular}{|c|c|c|c|c|c|c|c|c|}
\hline \multirow[b]{2}{*}{$\mathrm{R}$} & \multirow[b]{2}{*}{$\begin{array}{c}\text { Field } \\
\mathrm{R}\end{array}$} & \multirow[b]{2}{*}{$\begin{array}{l}\text { Moderated } \\
\text { Field R }\end{array}$} & \multirow{2}{*}{$\begin{array}{l}\text { Estimation error } \\
\text { standard deviation }\end{array}$} & \multicolumn{5}{|c|}{ The statistical Changes } \\
\hline & & & & $\begin{array}{c}\text { Field } \\
\text { Changes R }\end{array}$ & $\begin{array}{c}\text { Changes } \\
\text { F }\end{array}$ & $\begin{array}{l}\text { The first degree of } \\
\text { freedom }\end{array}$ & $\begin{array}{c}\text { the second degree } \\
\text { of freedom }\end{array}$ & $\begin{array}{c}\text { A significant factor of } \\
\text { changes } F\end{array}$ \\
\hline $.531^{\mathrm{a}}$ & .287 & .273 & .69928 & .287 & 49.309 & 1 & 133 & .000 \\
\hline
\end{tabular}

Table 2(a). Analysis of variance

\begin{tabular}{ccccccc}
\hline \multirow{2}{*}{ Model } & total squares & $\begin{array}{c}\text { Degree of } \\
\text { freedom }\end{array}$ & Average total & F & A significant factor \\
\hline \multirow{3}{*}{1} & Regression & 16.766 & 1 & 18.763 & 49.309 & $.000^{\mathrm{a}}$ \\
\cline { 2 - 7 } & Remain & 83.400 & 133 & .420 & & \\
\cline { 2 - 7 } & Total & 100.166 & 124 & & & \\
\hline
\end{tabular}

a. Prediction: (fixed), human factors

b. The dependent variable: the development of educational technology 
Table 2(b). Coefficients

\begin{tabular}{ccccccc}
\hline \multirow{2}{*}{ Model } & \multicolumn{2}{c}{ The non-standardized coefficients } & $\begin{array}{c}\text { The standardized } \\
\text { coefficients }\end{array}$ & & A significant \\
\cline { 3 - 6 } & & Regression Line & $\begin{array}{c}\text { The Error of } \\
\text { standard deviation }\end{array}$ & Beta & & Factor \\
\hline \multirow{2}{*}{1} & (Fixed) & 1.701 & .265 & & 6.528 & .000 \\
\cline { 2 - 6 } & Human Factors & .442 & .067 & .441 & 6.572 & .000 \\
\hline
\end{tabular}

a. The dependent variable: the development of educational technology

As you can see, the correlation coefficient amount between these two variables is 0.531 , which indicates a positive correlation between these two variables. $R^{2}$ is estimated 0.287 that shows $29 \%$ of the educational technology development is related to the human factors variable.

Since in the above table Sig, the equality test for regression coefficient and a constant with zero, is smaller than 0.05 , therefore the assumption based on the equality of the regression coefficients and a constant with zero will be rejected and they should not be removed from the Regression equation, in this way the regression equation is shown as below

$$
\mathrm{Y}=\alpha+\mathrm{bx}
$$

\section{Human Factors $=\mathrm{X}$}

\section{Educational Technology Development $=$ Y}

According to the regression coefficient in the table, it can be said that for each unit increase in human factors, the training technology development will change to the size of 2.143 and with respect to its significance level (Sig = $0.00<0.05$ ), the null hypothesis based on the zero value of this index will be rejected and this amount is the significant impact. In other words, with 95 percent confidence level, the first hypothesis about the impact of human factors on the development of educational technology will be confirmed.

The second main hypotheses: cultural factors as the development of educational technology obstacle have impacts on the teaching process in primary schools.

Table 3. Regressions between cultural factors and the development of educational technology

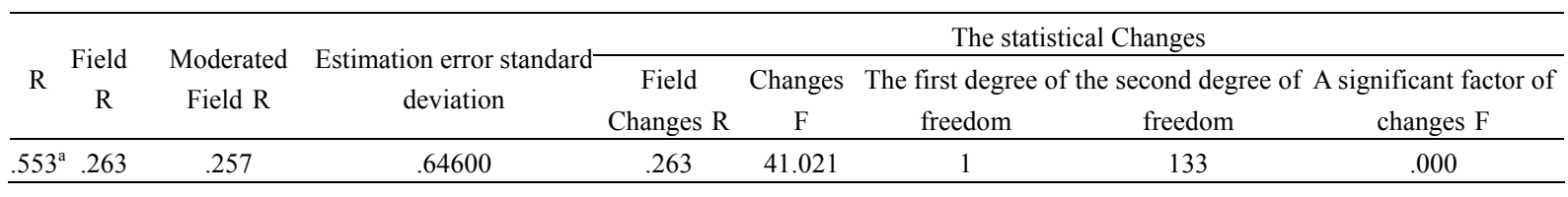

Table 3(a). Analysis of variance

\begin{tabular}{ccccccc}
\hline \multirow{2}{*}{ Model } & total squares & $\begin{array}{c}\text { Degree of } \\
\text { freedom }\end{array}$ & Average total & F & $\begin{array}{c}\text { A significant } \\
\text { factor }\end{array}$ \\
\hline \multirow{3}{*}{1} & Regression & 13.294 & 1 & 16.214 & 41.021 & $.000 \mathrm{a}$ \\
\cline { 2 - 7 } & Remain & 86.872 & 133 & .417 & & \\
\cline { 2 - 7 } & Total & 100.166 & 124 & & & \\
\hline
\end{tabular}

a. Prediction: (fixed), cultural factors

b. The dependent variable: the development of educational technology 
Table 3(b). Coefficients

\begin{tabular}{|c|c|c|c|c|c|c|}
\hline & \multirow{2}{*}{ Model } & \multicolumn{2}{|c|}{ The non-standardized coefficients } & \multirow{2}{*}{$\begin{array}{c}\text { The standardized } \\
\text { coefficients } \\
\text { Beta }\end{array}$} & \multirow{2}{*}{$\mathrm{T}$} & \multirow{2}{*}{$\begin{array}{c}\text { A significant } \\
\text { Factor }\end{array}$} \\
\hline & & Regression Line & $\begin{array}{c}\text { The Error of } \\
\text { standard deviation }\end{array}$ & & & \\
\hline \multirow{2}{*}{1} & (Fixed) & 1.556 & .312 & & 6.152 & .000 \\
\hline & Cultural Factors & .486 & .069 & .413 & 6.217 & .000 \\
\hline
\end{tabular}

a. The dependent variable: the development of educational technology

As you can see, the correlation coefficient amount between these two variables is 0.553 , which indicates a positive correlation between these two variables. $R^{2}$ is estimated 0.263 that shows $26 \%$ of the educational technology development is related to the cultural factors variable.

Since in the above table Sig, the equality test for regression coefficient and a constant with zero, is smaller than 0.05 , therefore the assumption based on the equality of the regression coefficients and a constant with zero will be rejected and they should not be removed from the Regression equation, in this way the regression equation is shown as below

$$
\mathrm{Y}=\alpha+\mathrm{bx}
$$

\section{Cultural Factors $=\mathrm{X}$}

\section{Educational Technology Development $=\mathrm{Y}$}

According to the regression coefficient in the table, it can be said that for each unit increase in cultural factors, the educational technology development will change to the size of 2.042 and with respect to its significance level ( $\operatorname{Sig}=0.00<0.05)$, the null hypothesis based on the zero value of this index will be rejected and this amount is the significant impact. In other words, with 95 percent confidence level, the first hypothesis about the impact of cultural factors on the development of educational technology will be confirmed.

The third main hypotheses: Physical factors as the development of educational technology obstacle have impacts on the teaching process in primary schools.

Table 4. Regressions between physical factors and the development of educational technology

\begin{tabular}{ccccccccc}
\hline & & & & \multicolumn{3}{c}{ The statistical Changes } \\
\cline { 6 - 9 } & Field R & $\begin{array}{c}\text { Moderated } \\
\text { Field R }\end{array}$ & $\begin{array}{c}\text { Estimation error } \\
\text { standard deviation }\end{array}$ & Field Changes R & Changes F & $\begin{array}{c}\text { The first } \\
\text { degree of } \\
\text { freedom }\end{array}$ & $\begin{array}{c}\text { the second } \\
\text { degree of } \\
\text { freedom }\end{array}$ & $\begin{array}{c}\text { A significant } \\
\text { factor of } \\
\text { changes F }\end{array}$ \\
\hline $.472^{\mathrm{a}}$ & .294 & .218 & .62969 & .294 & 47.602 & 1 & 133 & .000 \\
\hline
\end{tabular}

Table 4(a). Analysis of variance

\begin{tabular}{ccccccc}
\hline \multirow{2}{*}{ Model } & total squares & $\begin{array}{c}\text { Degree of } \\
\text { freedom }\end{array}$ & Average total & F & A significant factor \\
\hline \multirow{3}{*}{1} & Regression & 22.467 & 1 & 17.418 & 47.602 & $.000^{\text {a }}$ \\
\cline { 2 - 7 } & Remain & 77.699 & 133 & .347 & & \\
\cline { 2 - 7 } & Total & 100.166 & 124 & & & \\
\hline
\end{tabular}

a. Prediction: (fixed), Physical factors

b. The dependent variable: the development of educational technology 
Table 4(b). Coefficients

\begin{tabular}{|c|c|c|c|c|c|c|}
\hline & \multirow{2}{*}{ Model } & \multicolumn{2}{|c|}{ The non-standardized coefficients } & \multirow{2}{*}{$\begin{array}{c}\text { The standardized } \\
\text { coefficients } \\
\text { Beta }\end{array}$} & \multirow{2}{*}{$\mathrm{T}$} & \multirow{2}{*}{$\begin{array}{l}\text { A significant } \\
\text { Factor }\end{array}$} \\
\hline & & Regression Line & $\begin{array}{c}\text { The Error of } \\
\text { standard deviation }\end{array}$ & & & \\
\hline \multirow{2}{*}{1} & (Fixed) & 1.516 & .359 & & 5.154 & .000 \\
\hline & Physical Factors & .442 & .096 & .477 & 6.285 & .000 \\
\hline
\end{tabular}

a. The dependent variable: the development of educational technology

As you can see, the correlation coefficient amount between these two variables is 0.472 , which indicates a positive correlation between these two variables. $R^{2}$ is estimated 0.294 that shows $29 \%$ of the educational technology development is related to the physical factors variable.

Since in the above table Sig, the equality test for regression coefficient and a constant with zero, is smaller than 0.05 , therefore the assumption based on the equality of the regression coefficients and a constant with zero will be rejected and they should not be removed from the Regression equation, in this way the regression equation is shown as below

$$
\mathrm{Y}=\alpha+\mathrm{bx}
$$

\section{Physical Factors $=\mathrm{X}$}

\section{Educational Technology Development $=\mathrm{Y}$}

According to the regression coefficient in the table, it can be said that for each unit increase in physical factors, the educational technology development will change to the size of 1.958 and with respect to its significance level ( $\operatorname{Sig}=0.00<0.05)$, the null hypothesis based on the zero value of this index will be rejected and this amount is the significant impact. In other words, with 95 percent confidence level, the first hypothesis about the impact of cultural factors on the development of educational technology will be confirmed.

The fourth main hypotheses: Courses content as the development of educational technology obstacle have impacts on the teaching process in primary schools.

Table 5. Regressions between Courses content and the development of educational technology

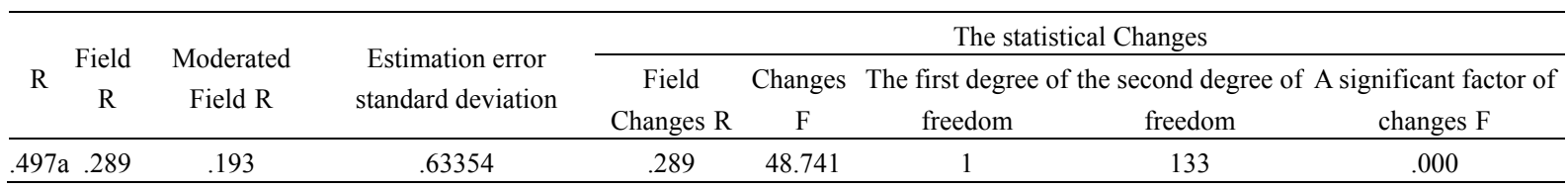

Table 5(a). Analysis of variance

\begin{tabular}{ccccccc}
\hline \multirow{2}{*}{ Model } & total squares & $\begin{array}{c}\text { Degree of } \\
\text { freedom }\end{array}$ & Average total & F & $\begin{array}{c}\text { A significant } \\
\text { factor }\end{array}$ \\
\hline \multirow{3}{*}{1} & Regression & 49.505 & 1 & 18.514 & 48.741 & $.000 \mathrm{a}$ \\
\cline { 2 - 7 } & Remain & 50.661 & 133 & .396 & & \\
\cline { 2 - 7 } & Total & 100.166 & 124 & & & \\
\hline
\end{tabular}

a. Prediction: (fixed), Courses content

b. The dependent variable: the development of educational technology 
Table 5(b). Coefficients

\begin{tabular}{|c|c|c|c|c|c|c|}
\hline & \multirow{2}{*}{ Model } & \multicolumn{2}{|c|}{ The non-standardized coefficients } & \multirow{2}{*}{$\begin{array}{c}\text { The standardized } \\
\text { coefficients } \\
\text { Beta }\end{array}$} & \multirow{2}{*}{$\mathrm{T}$} & \multirow{2}{*}{$\begin{array}{l}\text { A significant } \\
\text { Factor }\end{array}$} \\
\hline & & Regression Line & $\begin{array}{c}\text { The Error of } \\
\text { standard deviation }\end{array}$ & & & \\
\hline \multirow{2}{*}{1} & (Fixed) & 1.506 & .271 & & 6.711 & .000 \\
\hline & Courses content & .451 & .074 & .462 & 6.143 & .000 \\
\hline
\end{tabular}

a. The dependent variable: the development of educational technology

As you can see, the correlation coefficient amount between these two variables is 0.497 , which indicates a positive correlation between these two variables. $R^{2}$ is estimated 0.289 that shows $29 \%$ of the educational technology development is related to the courses content variable.

Since in the above table Sig, the equality test for regression coefficient and a constant with zero, is smaller than 0.05 , therefore the assumption based on the equality of the regression coefficients and a constant with zero will be rejected and they should not be removed from the Regression equation, in this way the regression equation is shown as below

$$
\mathrm{Y}=\alpha+\mathrm{bx}
$$

$$
\text { Course content }=\mathrm{X}
$$

Educational Technology Development $=\mathrm{Y}$

According to the regression coefficient in the table, it can be said that for each unit increase in courses content, the educational technology development will change to the size of 1.957 and with respect to its significance level ( $\operatorname{Sig}=0.00<0.05)$, the null hypothesis based on the zero value of this index will be rejected and this amount is the significant impact. In other words, with 95 percent confidence level, the first hypothesis about the impact of cultural factors on the development of educational technology will be confirmed.

\section{Conclusion}

The aim of this study was to examine the use of educational technology barriers in the learning process of students in primary schools of district 13 in Tehran. For this purpose, according to the research, theoretical literature four hypotheses were evaluated. In accordance with the results the human factors, cultural factors, physical factors and course content variability have been identified as effective factors on the development of educational technology in primary schools.

Human factors studies showed that the use of educational technology in teaching and learning process will create prevention, this research finding is consistent with Nourali Pour (1995) investigations. In previous studies, it has been concluded that the lack of providing services to teachers, computer science weakness in teachers, teacher resistance to the changes as benefit barriers of educational technology in the process of learning and teaching, will be effective.

\section{References}

Ahadian, M. (2000). The preparation of educational technology. Tehran, Ayish.

Ahadian, M. (2008). The theoretical preparation of Educational Technology. Bashari publishing and promoting, Tehran.

Ahadian, M., \& Aghazadeh, M. (2000). The guidance of new teaching methods for education and training. Ayish, Tehran.

Al-Alawneh, M. K. (2013). Examining E-learning barriers as perceived by faculty members of Engineering Colleges in the Jordanian Universities. International Journal of Vocational and Technical Education, 5(4), 42-53.

Clayton, A. W. (2006). Overview and Evolution of the ADDIE Training System, Advances in developing Human Resources, 8(4), 430-441. https://doi.org/10.1177/1523422306292942

Constantino, G. D. (2014). Educational Technology and Teacher Education: Barriers and Gates in South America. Creative Education, 1080-1085.

Enayati, T., Zameni, F., Qazlesfely., M., Rayis-Poor, A., \& Forghani, M. (2011). The study of teachers' benefiting barriers of educational technology in the process of teaching and learning. Regional Conference of 
Psychology and Education.

Fardanesh, H. (2009). Theoretical Foundations of Educational Technology. Samt publishing, Tehran.

Park, S. H., \& Ertmer, P. A. (2008). Examining barriers in technology-enhanced problem-based learning: Using a performance support systems approach. British Journal of Educational Technology, 39(4), 631-643.

Veladkofsky. (2011). The passion for learning (Translation: Mohammad Panahi). Ney Publishing, Tehran.

\section{Copyrights}

Copyright for this article is retained by the author(s), with first publication rights granted to the journal.

This is an open-access article distributed under the terms and conditions of the Creative Commons Attribution license (http://creativecommons.org/licenses/by/4.0/). 